\title{
Towards a New, Digital Communication Paradigm
}

\author{
Jelena Perovic \\ Correspondence: Jelena Perovic, Sapienza University of Rome, Italy \\ Received: May 5, 2016 Accepted: May 18, 2015 Online Published: May 27, 2016 \\ doi:10.11114/smc.v4i1.1592 URL: http://dx.doi.org/10.11114/smc.v4i1.1592
}

\begin{abstract}
Updating of the key concepts of media education is absolutely necessary due to the changes introduced by the digital revolution. This article looks into the ways that the key media education concepts are modified in the digital age according to the ongoing, international scientific debate. It suggests their adapting to make them fully relevant to the digital media and participatory culture. The ongoing process of adaptation of the current paradigm of communication and media education is likely to lead, in future, to a new, digital communication paradigm. As a consequence, schools will need to adopt a corresponding new, digital education paradigm.
\end{abstract}

Keywords: digital communication paradigm, digital education paradigm, media education, media literacy

\section{Introduction}

Has the digital revolution resulted in a communication science revolution? A scientific revolution occurs with a paradigm shift: a transformation of the conceptual structure through which scientists look at the word (Kuhn, 1962). Key media education concepts must be updated due to the changes introduced by the digital revolution. However, even though they are modified, these concepts are still valid. Hence, a radical change in the vision that guides theoretical reflections and empirical research in communication science and media education has still not happened. Instead, we are now, probably, at the dawn of a communication science revolution.

This article looks into the ways that key media education concepts are modified after the digital revolution according to the ongoing, international scientific debate.

Media education is used in this article to refer to the process of developing abilities to access, understand, critically analyze, assess and produce messages using all available media. The result of this continuous process is media literacy.

Table 1 presents key media education concepts as described by different scientists and media education centers. Concepts in the same raw refer to the same thing. For example, the first raw refers to the question of "who" produced a certain message, which some investigate under the concept entitled "author" and others use terms like construction, media production, media agencies, media institutions or ideological analysis. Similarly, the second raw refers to the question of "how" a message is constructed. This question is explored using terms like the format, technics, technologies, languages, genres, narration, production elements analysis and nonverbal communication. The third raw refers to the question "for whom" the message is produced. It is mostly explored under the concept of "audience". The forth raw refers to the difference between the real world and the one presented by media. Most often, this question is investigated within the concepts of content and representation. Finally, the last raw is related to the research about the impact of media, which is most often referred to with the term "purpose". 
Table 1. Comparison of the key concepts of media education according to different authors and media education centers

\begin{tabular}{|c|c|c|c|c|c|c|c|c|}
\hline $\begin{array}{l}\text { Center } \\
\text { for } \\
\text { Media } \\
\text { Literacy } \\
\text { (USA) }\end{array}$ & $\begin{array}{l}\text { Associatio } \\
\text { n for } \\
\text { Media } \\
\text { Literacy } \\
\text { Canada }\end{array}$ & $\begin{array}{l}\text { National } \\
\text { Association } \\
\text { of Media } \\
\text { Literacy } \\
\text { (NAMLE), } \\
\text { USA } \\
\end{array}$ & $\begin{array}{l}\text { British Film } \\
\text { Institute }\end{array}$ & $\begin{array}{l}\text { Buckingham } \\
(2003)\end{array}$ & $\begin{array}{l}\text { Gonnet } \\
\text { (2001) }\end{array}$ & $\begin{array}{l}\text { Silverblatt, } \\
\text { Ferry \& Finan } \\
(\mathbf{2 0 0 9 )}\end{array}$ & $\begin{array}{l}\text { Lavender, } \\
\text { Tufte \& } \\
\text { Lamish (Eds) } \\
\text { (2003) }\end{array}$ & $\begin{array}{l}\text { Hobbs } \\
(2011)\end{array}$ \\
\hline $\begin{array}{l}\text { Authorshi } \\
\text { p }\end{array}$ & $\begin{array}{l}\text { Constructio } \\
\mathrm{n}\end{array}$ & $\begin{array}{l}\text { Authorship, } \\
\text { economics }\end{array}$ & $\begin{array}{l}\text { Media } \\
\text { agencies }\end{array}$ & $\begin{array}{l}\text { Media } \\
\text { production }\end{array}$ & $\begin{array}{l}\text { Media } \\
\text { institutions }\end{array}$ & $\begin{array}{l}\text { Ideological } \\
\text { analysis }\end{array}$ & Institutions & Authors \\
\hline Format & Format & Techniques & $\begin{array}{l}\text { Languages, } \\
\text { genres, } \\
\text { technologies }\end{array}$ & $\begin{array}{l}\text { Language, } \\
\text { media } \\
\text { production }\end{array}$ & $\begin{array}{l}\text { Genres, } \\
\text { technologies, } \\
\text { language }\end{array}$ & $\begin{array}{l}\text { Production } \\
\text { Elements } \\
\text { Analysis; } \\
\text { Nonverbal } \\
\text { communication } \\
\text { analysis }\end{array}$ & $\begin{array}{l}\text { Technologies, } \\
\text { languages, } \\
\text { genre, } \\
\text { narration }\end{array}$ & $\begin{array}{l}\text { Messages and } \\
\text { Meanings }\end{array}$ \\
\hline Audience & Audience & $\begin{array}{l}\text { Response, } \\
\text { interpretation } \\
\mathrm{s}\end{array}$ & Audience & Audience & Audience & $\begin{array}{l}\text { Autobiographic } \\
\text { al analysis }\end{array}$ & Audience & Audiences \\
\hline Content & Content & $\begin{array}{l}\text { Content, } \\
\text { credibility }\end{array}$ & $\begin{array}{l}\text { Representatio } \\
\mathrm{n}\end{array}$ & $\begin{array}{l}\text { Representatio } \\
\mathrm{n}\end{array}$ & $\begin{array}{l}\text { Representatio } \\
\mathrm{n}\end{array}$ & Mythic analysis & $\begin{array}{l}\text { Representatio } \\
\text { ns }\end{array}$ & $\begin{array}{l}\text { Representatio } \\
\mathrm{n} \text { and Reality }\end{array}$ \\
\hline Purpose & Purpose & $\begin{array}{l}\text { Purpose, } \\
\text { impact }\end{array}$ & $\begin{array}{l}\text { Media } \\
\text { agencies }\end{array}$ & $\begin{array}{l}\text { Media } \\
\text { production }\end{array}$ & $\begin{array}{l}\text { Media } \\
\text { institutions }\end{array}$ & $\begin{array}{l}\text { Ideological } \\
\text { analysis }\end{array}$ & Institutions & Authors \\
\hline
\end{tabular}

Description: This table connects the key concepts discussed by different authors and media education centers and compares them across five key media education questions: who produced a message (raw 1), how (raw 2), for whom (raw 3), with what meanings (raw 4) and effects (raw 5).

Based on the comparison of the key concepts identified by different authors and media education centers, a conceptual map of media education is constructed in the Figure 1. It consists of five key concepts: author, format, content, audience and impact.

1. Author includes the meaning of the concepts often discussed using the terms like construction, institutions, media agencies, economics, etc. It is not just about identifying the author of a message, but also about the copyright and media ownership or the social and economic system behind the process of creation and distribution of messages (Hartley, 2011).

2. Format is related to the genre studies and the analysis of the narrative structure. Genre connects the media industry with the audiences. Producers use a particular genre to attract a specific type of audience who knows what to expect from a certain product thanks to its classification through the genre. Finally, media critics use the genre to classify media and establish a system of values and cultural status (Branston, 2006; Hartley, 2011; McQuail, 2007).

3. Content refers to what media are communicating - representations of reality. Debate about the content generally refers to the representations that media transmit and their impact on different audiences, especially on the most vulnerable one - children.

4. Audience describes a temporary group of people who do not need to be related to each other and do not necessarily share the same identity, but consume the same cultural product (Hartley, 2011; McQuail, 2007). The concept of audience is much older than the one of mass media, as the innovation of mass media consisted of eliminating the need for the members of the audience to be present at the same location at the same time. (Livingstone, 2005). Media industry considers audiences as a market of potential or real consumers whose socio-economic profile is known (McQuail, 2007). There is a long tradition of audience research, which started off with a focus on social issues like the impact of media on violent behaviors of individuals. Recently, it is more focused on issues related to the way variables like the class, gender, family background, ethnicity, fandom, etc. condition the way audiences interact with different media messages (Hartley, 2011). The introduction of the concept of "active audience" made a significant change in the tradition of research on this topic.

5. Impact is related to the studies and theories of the effects of media. In times of crisis, belief in the power of media is usually strengthened due to the lack of sufficient information from other sources or direct experiences (McQuail, 2007).

Conceptual map in the Figure 1 presents the key issues related to the transformations of the meanings of each concept according to the ongoing, international scientific debate. 


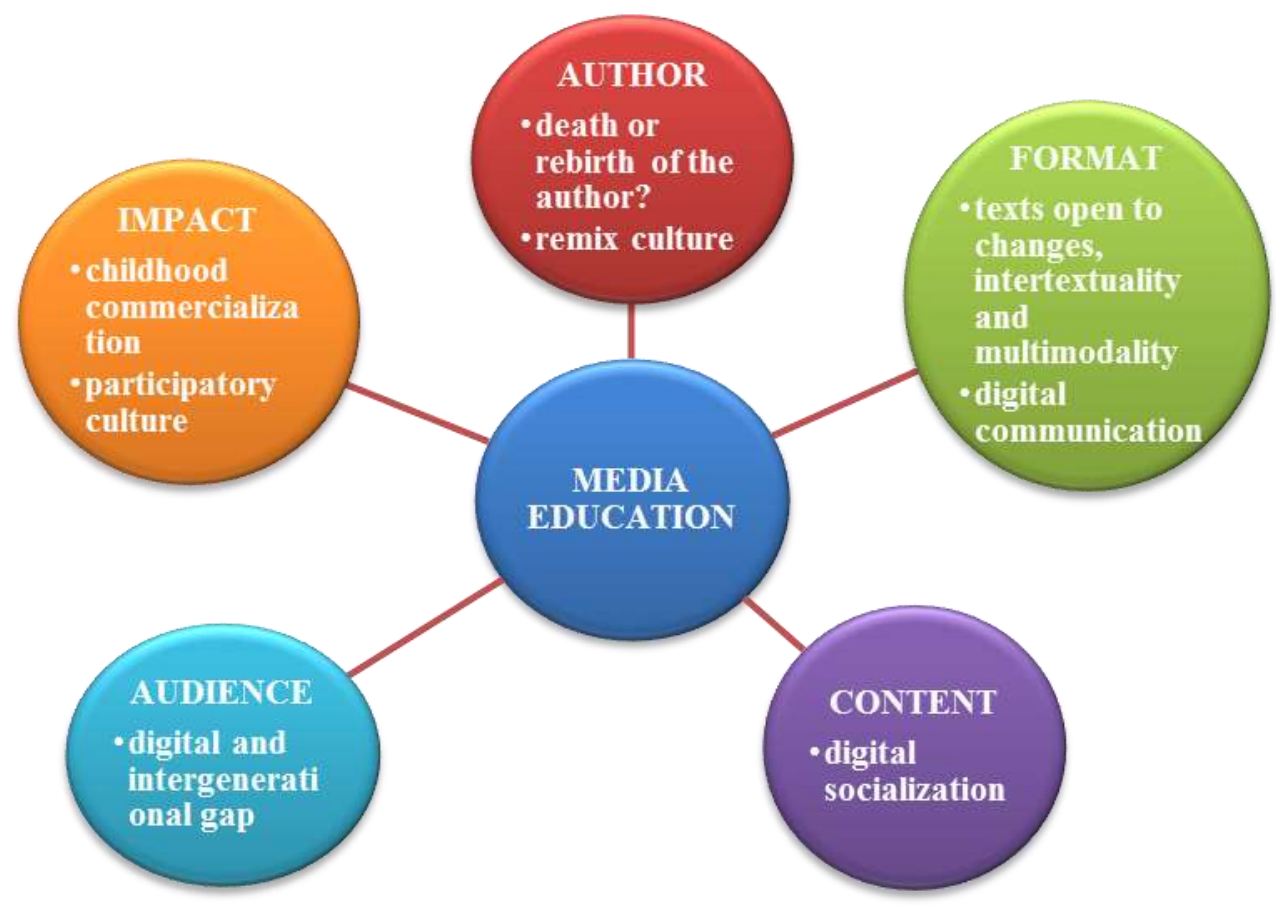

Figure 1. Media education conceptual map

Description: This conceptual map presents key media education concepts based on the comparison of the key concepts used by different scientists and media education centers. For each concept, the map appoints to the key issues discussed in relation to the changes of its meaning after the digital revolution.

\section{Method}

A review of international scientific literature was based on the search of the most recent scientific publications. Search terms included "media education", "media literacy", "new (media) literacies", digital literacy", "digital competencies", "children", "youth", "digital natives", "digital immigrants", "millennials", "media", "communication", "education", "culture", "digital age", "digital revolution", "author", "audience”, "media production", "media representation", "media impact", etc. Titles and abstracts of identified publications were checked for relevance before being included in the review.

\section{Results}

Media education key concepts analyzed as a result of the international scientific literature review include author, format, content, audience and impact.

\subsection{Author}

\subsubsection{The Death of the Author?}

According to Jones and Hafner (2012), digital revolution made the read-only web become a read-write web. As a consequence, "in many digital texts, the author simply does not exist anymore... in the near future, it will be more and more difficult, and maybe at some point even impossible, to say who the author of a text is". (Simone, 2012, p.95, 115).

However, this phenomenon can also be interpreted as the rebirth of the author. Thanks to the digital media, more people of different backgrounds can easily become authors, express themselves and participate in the public sphere. The society becomes more inclusive and the public sphere is healthier (Carrington \& Robinson, 2009; Gee, 2013; Hobbs, 2011; Jenkins \& Kelley, 2013; Jones \& Hafner, 2012).

Moreover, participation and active collaboration of a great number of people both in the role of an author and of an audience can make humanity more intelligent. Apropos, Jones and Hafner (2012) talk about the "peer production" to refer to the situations when large numbers of persons from all over the world are connected through the digital media and work together on a voluntary basis to promote projects of common interest. These big groups of peers can be so efficient to compete with traditional organizations like governments and corporations. Gee (2013) presents a similar idea with the concept of "synchronized intelligence" and cites "affinity spaces" as examples of this new culture. Many different people with diverse knowledge, tools and skills are connected in affinity spaces in ways that make each one of them more intelligent and the entire space of their interaction becomes a form of common intelligence. 
This idea, though, is not completely new. Levy (1997) already talked about "collective intelligence". However, digital revolution has facilitated the collaboration of great numbers of people, which is necessary to achieve collective intelligence.

This process, though, is not automatic. Online spaces can also be dominated by people who share the same opinions and use them to strengthen their prejudices instead of broadening their horizons through interaction with people who think differently. In such situations, affinity spaces become the contrary of the synchronized intelligence (Gee, 2013).

Not only the paradigm of the author, but also the one of the expert, is in crisis in the participatory culture. For example, Jenkins and Kelley (2013) introduce the concept of the "distributed expertise" to describe the situations when knowledge is disseminated through a large network of people and tools and everyone can access it.

Wikipedia is an example of what is described as collective intelligence, synchronized intelligence, distributed expertise and peer production. Jones and Hafner (2012), as well as other scientists (Adams \& Burke, 2009; Carrington \& Robinson, 2009; Jenkins \& Kelley, 2013), note how Wikipedia, even though its authors are volunteers, can compete for accuracy with encyclopedias produced by experts like the Encyclopedia Britannica. As a product of participatory culture, Wikipedia puts in crisis the "moral economy of information" on which the traditional, authoritative encyclopedias written by experts are based. Hence, participatory culture is changing the relationship between the expertise, the right to produce and disseminate texts and the role of the author.

"In 2005, after much speculation, the science journal Nature published the results of their survey of the comparative accuracy of the Encyclopedia Britannica (online edition) and Wikipedia. The article reported that there was little effective difference in accuracy between the free, cooperative Wikipedia and the subscription service expertly created Encyclopedia Britannica. The furore over this finding was instructive. Encyclopedia Britannica took out a not inexpensive half-page advertisement in the Times demanding a reaction of the Nature story and its central claims. Nature refused." (Carrington \& Robinson, 2009, kindle loc 1587 of 3995)

This episode, as pointed out by Adams and Burke (2009), does not mean that Wikipedia has no mistakes, but that even credible sources like the Encyclopedia Britannica contain errors. According to Carrington and Robinson (2009), the issue of how to deal with the changes of the concept of the author caused by the digital revolution is at the essence of the concerns expressed about the credibility and reliability of Wikipedia.

Finally, innovations in the meaning of the concept of the author described so far are important for schools. Students need to develop competencies related to collective/synchronized intelligence, distributed expertise and peer production. Also, in the digital world flooded by information, it becomes crucial for students to develop skills needed to assess and compare different sources of information. Simply ignoring or distrusting new sources like the Wikipedia does not seem to be a good option. The ability to reflect on and evaluate the credibility of all authors and sources of information is essential for the media education in the digital age.

\subsubsection{Copyright in the Digital Age: the Remix Culture}

Through the legislation on the copyright, the concept of author gained an economic value. (Hartley, 2011). However, as pointed out by many scientists (Carrington \& Robinson, 2009; Hartley, 2011; Jenkins \& Kelley, 2013; Simone, 2012), digital revolution has caused a crisis of the economic system of the copyright, since digital media allow free copying, modifying and distribution of texts.

At the same time, digital revolution has facilitated the process of creation of new texts based on the existing ones. Remix indicates the process of modification of aspects of an existing text, while mashup refers to the mixing of two or more texts to make a new one (Jenkins \& Kelley, 2013; Jones \& Hafner, 2012; Manovich, 2007). Remixes and mashups are much more than a simple copy of other texts. To make them, one needs to reconstruct creatively the original material so that it can be inserted into the new context or to mix it with texts from other sources in order to create a new meaning (Jenkins and Kelley, 2013).

While remixing in the world of commercial music is acceptable, in other areas, it is considered a copyright violation (Manovich, 2007). The ongoing debate about the ethical and legal acceptability of remix and mashup is essentially about the conflict between the economy of copyright and the public interest to allow citizens to access information. This last option helps avoid the creation of a democratic deficit.

According to Manovich (2007), we are living in a remix culture since the World Wide Web has contributed to defining an electronic document as a mix of other documents. Jones and Hafner (2012), on the other side, point out that the remix culture has always existed and that mashups and remixes challenge us to reconsider our beliefs about the originality, intellectual property and ethics. In the print media, the most obvious predecessor of these practices is quoting, when the author literally includes other author's words in the text. Despite the fact that such a text builds on previous ones, most people consider it to be original. "In fact, we can take this further by pointing out that, if you think 
about it, all original texts build on previous texts in some ways." (Jones \& Hafner, 2012, kindle loc 1348 of 5961 ).

Similarly, Jenkins and Kelley (2013) explain that the new model of the author developed after the digital revolution is not so different from the past one if one takes into account the myths of the creative genius and intellectual property widely spread since Romanticism. Codification of the copyright law in the late $19^{\text {th }}$ Century suggests that the concept of the protection of intellectual property is a recent invention. "This ideal of "originality" only partially explains the works of someone like Shakespeare, who drew on the material of other playwrights and fiction writers for plots, characters, themes, and turns of phrase". (Jenkins \& Kelley, 2013, kindle loc 2181 of 4643)

Therefore, as pointed out by Lessig (2004), copyright legislation acts as an obstruction to the creativity and cultural development, because it limits excessively the freedom to construct on other's work. It caused a shift from a free culture to a permission culture. In order to facilitate further cultural development, Lessig (2004) proposed an alternative ethical and legislative framework for copyright - the Creative Commons Licensing. It asks the author if the text can be used for remixes or mashups and if new texts must refer to the author of the original one, be non-commercial and sharable with others.

To conclude, an author in the digital age is at the same time the audience of the text. His/her products can be copied, modified and distributed easily through the digital media. Hence, traditional paradigms of the author, expert and copyright are in crisis, while a new digital communication paradigm is taking shape. These changes are important for schools. They need to teach students the differences between plagiarism and remix and to make them capable of following the new rules and being part of the participatory culture.

\subsection{Format}

Digital texts can be changed easily. They are intertextual and multimodal. These features have a social impact, in particular in relation to young people, as they reflect on their languages, cognitive development, identities and social relations.

\subsubsection{Characteristics of the Digital Text: Continuously Open to Changes, Greater Intertextuality and Multimodality}

Digital texts can be modified by audiences, which was not possible in the past. This makes them instable and open. They can be accessed, sent and received anywhere, which makes them delocalized and immaterial. The sender does not have to be the author of the digital text. In short, a digital text can be disseminated without the limits of time, space and number of recipients, while each recipient can modify it and send it to new people without leaving traces of changes made. (Carrington \& Robinson, 2009; Ferri, 2011; Silverblatt \& Eliceri, 1997; Simone, 2012)

Not only the format of the text has changed, but also the way of "reading" it. While reading online, thanks to new technologies, people can make comments and notes and talk to authors and other readers (Jones and Hafner, 2012). As a result, a greater freedom of interpretation of texts is promoted in the digital age (McQuail, 2007). According to Hartley (2011), in the past, one meaning, that of the author, was most often attributed to the text. Recently, however, different interpretations by different audiences are considered. Discussion about the meanings between the audiences is facilitated through the digital media.

When it comes to the intertextuality, obviously, even the pre-digital texts had this feature, but the digital media have facilitated this process of a text combining elements of different genres or referring to other texts. The concept of intertextuality is closely related to the debate about the copyright, as it suggests that texts are based on the previous ones and that they do not have clear boundaries, as they always refer to other texts (Branston, 2006). Hypertext, however, is an innovation of the digital format. It allows one electronic text to be hyperlinked to another one. This feature affects the organization of the text by the author, as well as the way the reader navigates and reads it. By selecting the hypertexts and creating his/her own way of reading, the reader has a much more active role. On the other side, this presents a challenge for the authors, as it is more difficult to present an argument through hypertexts having in mind that readers can easily go away and consult other sources online. (Jones \& Hafner, 2012; Simone, 2012)

Thanks to the digital format, the message can be sent through images, audio, video and text at the same time. This makes digital texts multimodal. (Jones \& Hafner, 2012)

Such innovations in the format are relevant for education. Schools need to develop abilities of students to read and write effectively texts in both the traditional and digital format.

\subsubsection{Impact of the Digital Format on Communication, Cognitive Development, Identity and Social Relations}

As pointed out by Jones and Hafner (2012), digital communication should not be considered as an imperfect replication of the face-to-face or written communication. It has introduced new interactions in the social life, which were not possible before.

There is an ongoing debate about the effects of the multimodality of the digital text on communication in general. It is 
important to note that not everyone uses multimodality: even though almost all PCs now have web cameras and social networks make video chats easy to organize, the majority of people does not take part in such interactions (Jones \& Hafner, 2012). In fact, according to the Pew Research Center (2010), most people do not use these tools at all: during a typical day, only about $4 \%$ of Internet users take part in video calls, chat and teleconferences. Users, as pointed out by Jones and Hafner (2012), seem to prefer instant messaging, a form of communication with lower transaction costs, as during the verbal interactions one needs to pay attention to the tone of voice, facial expressions and gestures. Hence, the effects of multimodality seem to be limited by the little use of this type of communication in everyday life. However, with the greater use of smartphones, this situation can change. In fact, recent European research Net Children Go Mobile (Mascheroni \& Cuman, 2014) conducted among minors 9-16 years old, shows that $28 \%$ of the smartphone users upload photos or videos online every day, while only $10 \%$ of users without a smartphone do the same.

Impact of the digital communication on the language is widely discussed as well. According to many linguists (Huffaker \& Calvert, 2005; Witmer \& Katzman, 1997; etc.), the ways to use the emoticons, abbreviations, acronyms and other options of the digital communication vary with age, gender and territory of the user. Gee (2008) refers to the different styles of spoken and written language associated to the different people with the term social languages. He explains how different users of affinity spaces - those contributing to a blog; players of an online game; friends of a social network; etc. - tend to use different social languages. Similarly, according to Crystal (2008), users can use these particular social languages to exclude from interactions people who are not part of their group. For example, children use abbreviations like "prw ttyl" ("parents watching, talk to you later) to exclude parents from their online communication with peers. Crystal (2001) points out that digital media have introduced a new linguistic variety - netspeak. It contains various subcategories which correspond to the different digital media, like the email language, the language of chat groups, etc.

Scientists do not agree about the impact of the digital communication on the linguistic abilities of young people. Many are concerned, as they consider the language used by minors to be less rich due to the abbreviations, acronyms, emoticons and other features of the digital communication. On the other side, some research, like the one by Massey and colleagues (2005), shows that students who spent more time on instant messaging and texting tend to write more complex phrases, use a richer vocabulary and have a more accurate spelling in the English language tests. Similarly, studies conducted by Plester and colleagues (Plester, Wood \& Bell, 2008; Plester, Wood \& Joshi, 2009) point out that the students who often use the languages of SMS achieve better results at the standardized tests of English language. Finally, the survey by Baron (2004) on instant messaging of the US university students indicates that the language used online is not totally different from the standard one as is often claimed. In fact, Baron discovered that only $0.3 \%$ of words or symbols used by the students were abbreviations; less than $0.8 \%$ were acronyms and only $0.4 \%$ were emoticons.

Debate about the impact of digital texts on the cognitive development refers to the research with contrasting results. Some are concerned about the negative effects, while others point out to the positive ones. Anyway, it is worthwhile taking into consideration the influence of the social capital as a variable which can orient the results of such research in the negative or positive way.

According to Simone (2012), after the digital revolution, the predominance of the ear and non-alphabetic vision has returned and young people are at the forefront of this process. As a consequence, there is a decrease in reading and in the capacity to read due to the "friendliness" of vision. Similarly, Carr (2011) points out that reading with hypertexts can compromise the ability to read conventional texts and follow complex discourses. The research by Rowlands et al (2008) indicates that students who were earlier exposed to the hypertext have greater probability to develop the competencies needed for reading effectively while moving from one document to another. However, scientists are concerned that these students are not sufficiently developing competencies needed for following a complex, logical discourse without interruptions in a long, narrative work.

On the other side, some scientists note that diverse distractions from reading have always existed and so, people have developed strategies to deal with them. For example, Scollon and colleagues (1999) studied literacy practices of Hong Kong university students before the digital technologies became widely accessible. They found out that students were rarely focused on doing one thing and using one medium at a time. For example, they spoke to each other while watching TV and listening to music. Similarly, Jones and Hafner (2012) sustain that the polifocality - the situation when attention of the media user is distributed among the different sources of information - makes humans different from other species. The ability of multitasking is probably one of the crucial advantages which allowed the human species to survive. Digital communication has made polifocality more efficient and its effects, good or bad, depend on the circumstances. Veen and Vrakking (2006) agree with this and refer to multitasking with zapping (Veen \& Vrakking, 2006). Research by Dillon et al (1989) about how academics read print newspapers indicates that the best print media readers do not read the text linearly, but interact with it in creative and flexible ways. Finally, according to Jenkins and Kelley (2013), linear reading has been dominant only in the last 150 years. Before the novel emerged as the popular 
reading at the beginning of the $18^{\text {th }}$ Century, linear reading was not a norm among the European and American readers and cognitive development was not threatened by this fact.

International scientific debate is also focused on the effects of the digital communication on identities and social relations. Digital media allow people to play new roles and assume identities which are different from the ones they have in real life. Online anonymity allows the marginalized ones to express their opinions without fear. In this way, online role-playing allows people to live different identities, develop virtual relationships which would be improbable in the real life and thus, broaden their horizons (Gee, 2013; Jones \& Hafner, 2012).

In particular, Gee (2003) describes three identities developed through videogames. Projective identity results from the interaction of the real identity of the player with the virtual one. Players project their values and aspirations onto their virtual character. As a consequence, the projected identity allows the player to reflect on the values guiding the behavior of the virtual character. In this way, videogames, just like the literature, can be useful tools for people to immerge in, understand and assess critically different cultural models.

With the spreading of the social networks, people are more motivated to reveal their true identity online. However, the economic model behind the social networks - selling information about users to advertising agencies - has led to a commodification of identities (Jones \& Hafner, 2012). At the same time, the digital format has created new opportunities for socializing within the cybersociety (Rheingold, 2013).

\subsection{Content}

All the arguments related to the content and media representations become more valid and relevant in the digital age due to the media convergence, greater multimodality and intertextuality of the digital texts. While new technologies allow the same message to be transmitted easily through the different media, within the digital socialization, minors actually gain more access to less content (Mazzarella (Ed), 2007). Thus, media education becomes crucial.

On one side, scientists are concerned that the omnipresence of messages amplifies their negative effects. On the other side, some hope that digital texts will lead to a greater positive interaction in the public sphere. Also, they can lead to the greater inclusion of the voices of young people and other vulnerable groups, which can result in the better quality of the content.

\subsection{Audience}

\subsubsection{Digital Divide}

Digital divide is transformed into the participation gap, as the ones without access and abilities to consume digital media become the new marginalizes groups (Jenkins, 2010).

According to the results of the 2009 OECD PISA test on the digital reading of 15 year olds in 19 European countries, the digital gap among young people is conditioned by their education, gender and socio-economic background. In fact, digital gaps reflect the socio-economic gaps within a country (Organization for Economic Cooperation and Development [OECD], 2011). Similarly, Buckingham (2003) points out to the surveys conducted in the UK in the ' 90 s, which showed that middle class children had three times greater probability of using a multimedia computer at home and eight times greater probability of navigating online that the working class children.

Buckingham, like other scientists (Cortoni, 2011; Gee, 2013; Hoechsmann \& Poyntz, 2012; Jenkins \& Kelley, 2013; Kotilainen et al, 2011), underlines that the differences in access are only a part of the problem, as there are important differences caused by the cultural capital. Students coming from the different socio-cultural backgrounds have a different cultural capital, which affects their knowledge and skills to use media creatively and productively. The recent EU Kids Online research confirms this thesis, as it indicates that the digital divide is more present in the South-Eastern European countries, where minors have fewer opportunities to access the Internet compared to their peers living in other parts of this continent. (Livingstone, Haddon, Gorzig \& Olafsson, 2011). A similar conclusion comes from the international research on the global digital gap among young people conducted by Kotilainen and colleagues (2011): the global digital divide spreads when going from the West and North to the East and South of the planet, or from rich towards the poor countries.

\subsubsection{Intergenerational Divide}

Intergenerational divide, now even bigger due to the digital one, seems to be determined by the fact that adults are embarrassed by young people's greater media experience and better competencies (Morcellini, 2007).

According to Tapscott (2009), the net generation is made of those born between 1977 and 1997, who are different from the previous generations because they grew up using the digital technology.

However, the boundary between the digital natives and immigrants cannot be identified precisely everywhere, because 
the process of transition to the greater use of the new technologies is happening gradually and differently across the countries. For example, according to Ferri (2011), in Italy, the date of birth of the digital natives needs to be set later than in some other Western countries due to the delay in the spread of the Internet across the country. In fact, massive diffusion of Internet in Italy happened in 1999-2000, which is the moment of birth of the Italian digital natives.

It is important to bear in mind that even within the group of the digital natives there are digital divides, as not all minors have developed digital competencies in the same way. Hence, Tapscott (2009) points out that a global net generation is only to be formed due to the existing digital divide. Moreover, many scientists (Buckingham, 2013; Gotz et al, 2005; Livingstone \& Helsper, 2006; Potter, 2013) warn about exaggerations of the terms like digital natives and net generation. As described by Potter (2013), children, as any other audience, are not all the same and, at every age, they have different levels of media literacy. Also, the fact of having lived for a longer period does not automatically make one person more media literate and less prone to the manipulation by media. In fact, the research by Livingstone and Helsper (2006) about the advertising literacy suggests that adolescents, and not the youngest children, are the most sensitive to advertising. They are the greatest consumers due to their bigger economic autonomy and peer pressure.

Recent research by the Pew Research Center (2010) in USA shows that the intergenerational gap is reflected on the ways of use of the digital media. Millennials, or the young people between 18 and 33 years, access the internet mostly though the Wireless from a laptop or a cell phone. Also, they are more engaged than older users in the use of social networks, instant messaging, listening to music online, playing games online, reading blogs and participating in virtual worlds. However, Generation X, or the users between 34 and 45 years, and older ones are more likely than the Millennials to visit government websites and look for financial information online. Finally, some online activities are common to all age groups: sending emails, online research of information on health, religion and news, online banking, purchasing of products and tickets online, etc.

\subsection{Impact}

Debate about the impact of the digital texts is mostly concerned by the effects on the most vulnerable audience children. The fear and incapacity to deal with the new situation presented by the digital media make a fertile ground for media panics, which transform the childhood into a battlefield regarding the wider problems of the society (Drotner \& Livingstone, 2008; Carrington \& Robinson, 2009).

One one side, scientists argue that the negative effects of media on children are greater in the digital age, as minors are more exposed to the same messages due to the media convergence. As a result, Postman's (1982) thesis about the death of childhood, caused by the access of children through media to the knowledge which was previously available to adults only, seems even more relevant today. According to the research, negative impact of media on children is reflected through their social isolation, difficulties with completing homework, passivity, less time dedicated to movement, play and reading, weakening of the authority of parents, bad nutrition and obesity, premature sexual experiences and depressive tendencies. (McQuail, 2007)

On the other side, many authors, like Prensky (2006) and Tapscott (2009), point out to the positive effects of the digital media on children. For example, greater access to the public sphere makes inclusion of the voices of minors in the society more likely. In fact, children are the greatest experts on childhood. Therefore, more research needs to be conducted with them to obtain a more accurate picture of what childhood means today (Cook, 2004; Corsaro, 2011; Holland, 2004; Kellett, 2010). Digital media can facilitate this process. Other positive effects refer to the support that media provide to children's socialization, formation of identity and development of fantasy (McQuail, 2007).

Finally, many risks to which minors are exposed online raise special concerns. It is interesting that the research conducted by Ito et al (2005) showed that participation of children in "networked publics" does not lead to behaviors that are more risky than the ones that children undertake in their offline life.

\subsubsection{Commercialization of Childhood in the Digital Age}

Media create a culture of the child consumer in order to increase the profits of the industry providing products and services for minors. Media convergence and the acceleration of the globalization after the digital revolution have intensified this phenomenon. For example, Tapscott (2009) introduces the term "prosumers" to describe young consumers of the digital age. They research products online before buying them. They expect a great variety of products and fast service. Prosumers consider entertainment to be a necessary part of the product. Finally, they are not happy with the standard products, but want to personalize them and buy them whenever and wherever. Through the Internet, prosumers access a great quantity of information. They can communicate with peers regarding the different products and services. In this way, "N-fluence networks" are born. These are online communities where young people exchange information and so, they are an important source of influence. Hence, companies have developed "marketing 2.0" to respond to the prosumers' needs. Tapscott describes it with the following keywords: everywhere, brand, communication, discovery and experience. 
Other authors also discuss about the intensification of the commercialization of childhood in the digital age. According to Hoechsmann and Poyntz (2012), there is a clear political economy of children's media. Four transnational companies - Disney, News Corp, Time Warner and Viacom - control the entertainment and media market for children, while another group of big, multinational corporations controls the industry of toys, videogames and food for minors. Through the new marketing and branding strategies for the digital age, like the interactive advertising (Mazzarella, 2007) and interactive marketing (Montgomery, Grier, Chester \& Dorfman, 2011), four key media companies for children help advertise globally the products made for them by the multinational corporations. Similarly, Wasko (2008) talks about the "commodification of youth culture" to describe this culture dominated by the proliferation of products and their advertising through the digital media in many ways. According to Jones and Hafner (2012), the economic model of social networks leads to the "commodification" of identities of young people.

Therefore, more research on the impact of the commercial messages in the digital media on the consumer mentality of children needs to be conducted taking into account that the situation will not be the same in the different parts of the world (Wasko, 2008).

\subsubsection{Socialization of Children in the Participatory Culture}

Within affinity spaces (Gee, 2013) and networked publics (Ito et al, 2009), children learn the social norms of public participation. In fact, after the digital revolution, one of the important objectives of the use of media has become taking part in the participatory culture. This is an online culture with low barriers for artistic expression and civic engagement; strong support for creation of messages and their sharing with others; informal mentoring by participants with greater expertise; participants who feel connected to each other and are convinced that sharing is important. (Jenkins, 2010)

In particular, young people's use of the digital media is usually friendship and interest driven (Ito et al, 2009). Their participation can vary from "hanging out" or socializing with friends online during free time, to "messing around" or searching for information online, playing with the video, digital cameras, cut-editing softwares and similar, and "geeking out". This last experience refers to the most intensive use of the digital media, as it requires a high level of technical knowledge and the willingness to modify or break the social and technological norms online. (Ito et al, 2009)

Therefore, the way to make friends and communicate with them is different in the digital age. According to Berg et al (2005), the exchange of online messages among young people, like the exchange of messages on cell phones, is actually an exchange of the "tokens of friendship". Recent research Net Children Go Mobile (Mascheroni \& Cuman, 2014) confirms this thesis: two of three minors 9 to 16 years old say to be in contact with friends through social networks and messaging applications several times a day. Minors see the constant access to friends as one of the key advantages of smartphones. For similar reasons, Jones and Hafner (2012) suggest that the digital revolution has not introduced an information age, but a relationship age, where the majority of people use digital media for connecting and communicating with each other. They see the key advantage of social networks in strengthening the "weak ties" or relationships with people with whom one is not so close. Net Children Go Mobile research confirms this thesis, as it shows that minors tend to expand their network of friends by communicating with friends of friends on social networks.

\section{Discussion \& Conclusion}

Due to the technological changes introduced by the digital revolution, the meaning of the key media education concepts has been transformed. The number of people who are not just the audience, but also the authors of media messages, or both at the same time, has significantly increased. As described in the international scientific debate, there has been a shift from an individual towards a collective engagement, collaboration and networking. As a consequence, media education key concepts and research methods need to be adapted to include the new criteria for researching the digital media and participatory culture. This process of adaptation of the current media education and communication paradigm is likely to lead, in future, to a new, digital communication paradigm. As a consequence, education systems will need to respond to this new context by adopting a corresponding new, digital education paradigm (Morcellini and Cortoni, 2007).

\section{References}

Adams, S. E., \& Burke, M. (2009). New Literacies: What Can Popular Culture Teach us about Information and Media Literacy? In Leaning M. (Ed.) Issues in Information and Media Literacy: Education, Practice and Pedagogy. Santa Rosa, CA: Informing Science Press.

Baron, N. (2004). See you online: Gender's issues in college student use of instant messaging. Journal of Language and Social Psychology 23, 397-423. http://dx.doi.org/10.1177/0261927X04269585

Berg, S., Taylor, A. S., \& Harper, R. (2005). Gift of the gab. In Harper, R., Palen, L. \& Taylor, A. S. (Eds.) The inside text: Social, cultural and design perspectives on SMS. Amsterdam: Springer, 271-285. http://dx.doi.org/10.1007/1-4020-3060-6_15 
Branston, G. (2006). Understanding genre. In Gillespie, M. \& Toynbee, J. (Eds.) Analysing media texts. Berkshire, UK: The Open University Press.

Buckingham, D. (2003). Media Education. Literacy, Learning and Contemporary Culture. Cambridge: Polity Press.

Buckingham, D. (edited by Andò, R. \& Cortoni, I.) (2013). David Buckingham. Media literacy in the digital culture to grow. Roma: Armando.

Carr, N. (2011). The shallows: What the internet is doing to our brains. New York: W. W. Norton and Co.

Carrington, V., \& Robinson, M. (2009). Digital Literacies: Social Learning and Classroom Practices. London, UK: Sage Publications. http://dx.doi.org/10.4135/9781446288238

Cook, D. (2004). The Commodification of Childhood: The Children's Clothing Industry and the Rise of the Child Consumer. Durham, NC: Duke University Press. http://dx.doi.org/10.1215/9780822385431

Corsaro, W. (2011). The Sociology of Childhood. Thousand Oaks, US: Sage Publications.

Cortoni, I. (2011). Young Digizen? New Cultural Challenges in Media Education. Milano: Franco Angeli.

Crystal, D. (2001). The Language of the Internet. Oxford: Oxford University Press. http://dx.doi.org/10.1017/CBO9781139164771

Crystal, D. (2008). Txting: The gr8 the db8. New York: Oxford University Press.

Dillon, A., Richardson, J., \& McKnight, C. (1989). The human factors of journal usage and the design of electronic text. Interacting with Computers 1(2), 183-189. http://dx.doi.org/10.1016/0953-5438(89)90025-8

Drotner, K., \& Livingstone S. (Eds.) (2008). The International Handbook of Children, Media and Culture. London: Sage Publications.

Ferri, P. (2011). Nativi digitali. Milano: Pearson Italia.

Gee, J. P. (2003). What Video Games Have to Teach Us About Learning and Literacy. New York: Palgrave Macmillan.

Gee, J. P. (2008). Social linguistic and literacies: Ideology in discourse, $3^{\text {rd }}$ edition. London, UK: Routledge.

Gee, J. P. (2013). The Anti-Education Era: Creating Smarter Students Through Digital Learning. New York, USA: Palgrave Macmillian.

Gonnet, J. (2001). Educazione, formazione e media. Roma: Armando.

Gotz, M., Lemish, D., Moon H., \& Aidman A. (2005). Media and the Make-Believe Worlds of Children: When Harry Potter Meets Pokemon in Disneyland. New Jersey, USA: Lawrence Erlbaum Associates, Inc .

Hartley, J. (2011). Communication, Cultural and Media Studies: The Key Concepts. $4^{\text {th }}$ edition. London: Routledge.

Hobbs, R. (2011). Digital and Media Literacy: Connecting Culture and Classroom. London: Sage Ltd.

Hoechsmann, M., \& Poyntz, S. R. (2012). Media Literacies: A Critical Introduction. West Sussex: Wiley-Blackwell. http://dx.doi.org/10.1002/9781444344158

Holland, P. (2004). Picturing Childhood: The Myth of the Child in Popular Imagery. London: I.B. Tauris.

Huffaker, D. A., \& Calvert, S. (2005). Gender, identity and language use in teenage blogs. Journal of Computer-Mediated Communication 10(2). http://dx.doi.org/10.1111/j.1083-6101.2005.tb00238.x

Ito, M., Horst, H., Bittanti, M., Boyd, D., Herr-Stephenson, B., Lange, P. G., Pascoe, C. J., \& Robinson L. (2009). Living and learning with new media. Summary of Findings from the Digital Youth Project. London, England: The MIT Press.

Jenkins, H. (2010). Culture partecipative e competenze digitali. Media Education per il XXI secolo. Milano: Angelo Guerini e Associati SpA.

Jenkins, H., \& Kelley, W. (2013). Reading in a Participatory Culture: Remixing Moby-Dick in the English Classroom. New York, USA: Teachers College, Columbia University.

Jones, R. H., \& Hafner, C. A. (2012). Understanding Digital Literacies: A Practical Introduction. New York, USA: Routledge.

Kellett, M. (2010). Rethinking Children and Research. Attitudes in Contemporary Society. London: Continuum International Publishing Group.

Khun, T. (1962). La struttura delle rivoluzioni scientifiche. Chicago: The University of Chicago Press. 
Kotilainen, S., Suoninen, A., Hirsjärvi, I., \& Kolomainen, S. (2011). 'Youngsters' Expressions of Responsible Citizenship through Media Diaries”. In Feilitzen, C., Carlsson, U. \& Bucht, C. (Eds.) New Questions, New Insights, New Approaches. Contributions to the Research Forum at the Worlds Summit on Media for Children and Youth 2010. Yearbook 2011., 213-225. Gothenburg: The International Clearinghouse on Children, Youth and Media at Nordicom.

Lavender, T., Tufte, B., \& Lamish, D. (Eds) (2003). Global Trends in Media Education: Policies and Practices. Cresskill, NJ: Hampton Press, Inc.

Lessig, L. (2004). Free culture: How big media uses technology and the law to lock down culture and control creativity. New York: Penguin Press.

Levy, P. (1997). Collective intelligence. New York, USA: Basic Books.

Livingstone, S. (2005). Media audiences, interpreters and users. In: Gillespie, M. (Ed) (2005) Media Audiences. Berkshire, UK: The Open University Press.

Livingstone, S., \& Helsper, E. (2006). Does advertising literacy mediate the effects of advertising on children? A critical examination of two linked research literatures in relation to obesity and food choice, Journal of Communication, 56, 560-584. http://dx.doi.org/10.1111/j.1460-2466.2006.00301.x

Livingstone, S., Haddon, L., Görzig A., \& Ólafsson K. (2011). Risks and safety on the internet: the perspective of European children: full findings and policy implications from the EU Kids Online survey of 9-16 year olds and their parents in 25 countries. EU Kids Online, Deliverable D4. EU Kids Online Network, London, UK. http://eprints.1se.ac.uk/33731/1/Risks\%20and\%20safety\%20on\%20the\%20internet\%281sero\%29.pdf

Manovich, L. (2007). What comes after remix? Retrieved from http://manovich.net/DOC-S/remix_2007_2.doc

Mascheroni, G., \& Cuman, A., (2014). Net Children Go Mobile: Final Report (with country fact sheets). Deliverables D6.4 and D5.3. Milano: Educatt. http://www.netchildrengomobile.eu/reports/

Massey, A. J., Elliott, G. L., \& Johnson, N. K. (2005). Variations in aspects of writing in 16+ English examinations between 1980 and 2004: Vocabulary, spelling, punctuation, sentence structure, non-standard English. Research Matters: A Cambridge Assessment Publication, Special Issue.

http://www.cambridgeassessment.org.uk/Images/173518-research-matters-special-issue-1.pdf

Mazzarella, S. R. (Ed.) (2007). 20 questions about youth \& the media. New York: Peter Lang.

McQuail, D. (2007). Sociologia dei Media. Quinta edizione. Bologna: Il Mulino.

Montgomery, K. C., Grier, S., Chester, J., \& Dorfman, L. (2011). Digital Marketing e Children's Health. A Framework for Research. In: VonFeilitzen, C., Carlsson, U. \& Bucht, C. (Eds) New Questions, New Insights, New Approaches. Contributions to the research forum at the world summit on media for children and youth 2010. Göteborg, Sweden: International Clearinghouse on Children, Youth and Media, Nordicom, Göteborg University.

Morcellini, M. (2007). Conclusione. In: Morcellini, M. \& Rivoltella, P.C. La sapienza di comunicare. Dieci anni di media education in Italia ed Europa. Gardolo (TN): Erickson.

Morcellini, M., \& Cortoni, I. (2007). Provaci ancora, scuola. Idee e proposte contro la svalutazione della scuola nel tecnoevo. Trento: Erickson.

OECD (2011) PISA 2009 Results: Students on Line: Digital Technologies and Performance (Volume VI) Retrieved from http://dx.doi.org/10.1787/9789264112995-en

Pew Research Center (2010). Generations 2010. Retrieved from http://www.pewinternet.org/files/old-media/Files/Reports/2010/PIP_Generations_and_Tech10.pdf

Plester, B., Wood, C., \& Bell, V. (2008). Txt Msg n school literacy: Does mobile phone use adversely affect children's literacy attainment? Literacy, 42(3), 137-144. http://dx.doi.org/10.1111/j.1741-4369.2008.00489.x

Plester, B., Wood, C., \& Joshi, P. (2009). Exploring the relationship between children's knowledge of text message abbreviations and school literacy outcomes. British Journal of Development Psychology 27(1), 145-161. http://dx.doi.org/10.1348/026151008X320507

Postman, N. (1982). The Disappearance of Childhood. New York, USA: Vintage Books.

Potter, J. (2013). Media Literacy. $6^{\text {th }}$ edition. London, UK: Sage Publications.

Prensky, M. (2006). Don't Bother Me Mom - I'm Learning! Minessota, MN: Paragon House. 
Rheinghold, H. (2013). Perché la rete ci rende intelligenti. Milano : Raffaelo Cortina. (original in English (2012) Net Smart. How to thrive online. Cambridge, MA: MIT Press.)

Rowlands, I., Nicholas, D., Williams, P., Huntington, P., Fieldhouse, M., \& Gunter, B. (2008). The google generation: The information behavior of the researcher of the future. Aslib Proceedings 60(4). http://dx.doi.org/10.1108/00012530810887953

Scollon, R., Bathia, V. K., Li, D. C. S., \& Yung, V. (1999). Blurred genres and fuzzy identities in Hong Kong public discourse: Foundational ethnographic issues. Applied linguistics, 20(1), $22-43$. http://dx.doi.org/10.1093/applin/20.1.22

Silverblatt, A., \& Eliceiri, E. M. E. (1997). Dictionary of Media Literacy. Westport, CT, USA: Greenwood Publishing Group.

Silverblatt, A., Ferry, J., \& Finan, B. (2009). Approaches to Media Literacy: a handbook. $2^{\text {nd }}$ edition. New York: M.E. Sharpe, Inc.

Simone, R. (2012). Presi nella rete. Milano: Garzanti.

Tapscott, D. (2009). Grown Up Digital. How the Net Generation is Changing Your World. New York: McGraw-Hill.

Veen, W., \&Vrakking, B. (2006). Homo Zappiens. Crescere nell'era digitale. Roma: Edizioni Idea.

Wasko, J. (2008). The Commodification of Youth Culture. In: Drotner, K. \& Livingstone, S. (Eds.) The International Handbook of Children, Media and Culture. London: Sage Publications. http://dx.doi.org/10.4135/9781848608436.n28

Witmer, D. F., \& Katzman, S. L. (1997). On-line smiles: Does gender make a difference in use of graphic accents? Journal of Computer-Mediated Communication, 2(4). http://dx.doi.org/10.1111/j.1083-6101.1997.tb00192.x

\section{(cc) EY}

This work is licensed under a Creative Commons Attribution 3.0 License. 